\title{
Ensino de História e a Lei 10.639/03: diálogos entre campos de conhecimento, diretrizes curriculares e os desafios da prática ${ }^{1}$
}

\author{
Lorene dos Santos*
}

\begin{abstract}
Resumo
Nos últimos anos, assistimos à emergência de uma legislação educacional cuja ênfase recai sobre o trato da diversidade sociocultural nos currículos escolares. A Lei 10.639/03, que torna obrigatório o ensino de história e cultura africana e afro-brasileira na educação básica, e a Lei $\mathrm{n}^{\mathrm{o}}$ 11.645/08, que ao lado desta temática inclui também a questão indígena como componente curricular obrigatório, se inserem nesse processo. A abordagem de culturas tradicionalmente negadas ou silenciadas nos currículos é compreendida como importante estratégia de combate às desigualdades historicamente perpetuadas em nossa sociedade, visando o empreendimento de uma reeducação das relações étnico-raciais. Esse texto busca elucidar aspectos da interface entre a produção acadêmica - especialmente a produção do campo historiográfico sobre o continente africano e sobre a escravidão negra -, a Lei 10.639/03 e suas Diretrizes Curriculares correlatas e o ensino de história, procurando ressaltar alguns dos desafios que se colocam hoje à prática pedagógica de professores da educação básica que assumem a responsabilidade de trabalhar tais conteúdos.
\end{abstract}

Palavras-chave: História e cultura africana e afro-brasileira; Educação antiracista; Historiografia; Ensino de história.

\section{Introdução}

Nos últimos anos, assistimos à emergência de uma legislação educacional que enfatiza o trato da diversidade sociocultural nos currículos escolares. Tal legislação atende a reivindicações históricas dos movimentos sociais organizados, sobretudo os movimentos negros e indígenas, e pode ser compreendida como parte dos esforços visando combater desigualdades historicamente perpetuadas em nossa sociedade. Dessa forma, tanto a Lei $\mathrm{n}^{\mathrm{o}} 10.639 / 03$, que trata da obrigatoriedade do ensino de história e culturas africana e afro-brasileira na educação básica, quanto a Lei 11.645/08, que, ao

\footnotetext{
${ }^{1}$ Este texto é parte de uma pesquisa de Doutorado em Educação intitulada "Saberes e Práticas em Redes de Trocas: a temática africana e afro-brasileira em questão", de Lorene dos Santos, defendida junto ao Programa de Pós-Graduação em Educação da Universidade Federal de Minas Gerais (UFMG), em 2010.

* Doutora em Educação pela Universidade Federal de Minas Gerais (UFMG). Professora do Departamento de História da Pontifícia Universidade Católica de Minas Gerais (PUC Minas).
} 
lado dessa temática inclui também a questão indígena como componente curricular obrigatório, põem em evidência a diversidade cultural - e étnico-racial - que nos identifica, ao mesmo tempo em que apontam para a necessidade de promovermos uma reeducação das relações étnico-raciais, em nosso país. Para tal legislação, isso implica em um sistemático combate a ideias e práticas racistas que ainda persistem em nosso imaginário e nas relações sociais, tendo como importante estratégia a valorização de histórias e culturas tradicionalmente negadas ou silenciadas nos currículos escolares.

É importante considerar, então, que a temática africana e afro-brasileira apresenta-se como conteúdo de fortes significações políticas e sociais, no âmbito da sociedade brasileira, e que sua abordagem nos currículos escolares, com ênfase para a perspectiva de reeducação das relações étnico-raciais, apresenta dilemas e desafios de ordem política, pedagógica, ética e epistemológica, entre outras dimensões.

Vale ressaltar, ainda, que o reconhecimento da História como uma das disciplinas escolares a se responsabilizar, privilegiadamente, pela educação das relações étnico-raciais na Educação Básica - como expresso na Lei nº 10.639/03 - obedece não apenas a critérios epistemológicos - a contribuição óbvia dessa disciplina para o estudo da história e cultura africana e afro-brasileira - mas a critérios político-sociais. Alvo de disputas e embates pela perpetuação e/ou instituição de memórias, o ensino de história tem sido, historicamente, palco de uma verdadeira "guerra de narrativas" (LAVILLE, 1999), podendo-se identificar diferentes vozes realizando distintas apropriações de discursos e narrativas históricas, em função de seus projetos políticos e concepções de mundo.

Dessa forma, seja por meio de discussões, da formulação de leis e propostas oficiais de ensino ou das pesquisas acadêmicas, as questões da valorização da pluralidade cultural e da denúncia e combate às desigualdades e injustiças sociais tem se tornado tema e problema para o ensino de história, podendo-se identificar um crescente e sistemático diálogo com alguns conceitos e categorias analíticas, tais como os conceitos de identidade, alteridade, memória e cultura. Essa incorporação evidencia uma aproximação cada vez maior da história com outros campos de saber, especialmente a antropologia e os chamados "estudos culturais", que englobam múltiplas abordagens e articulações disciplinares. Caimi nos lembra que a chegada de tais discussões ao ensino de história é parte de um movimento maior que, embora não hegemônico, se expressa em nível mundial, pela 
[...] tendência a conceber o outro não como inferior, mas como diferente; em defender o direito de as culturas vivenciarem plenamente sua alteridade; a valorizar as experiências individuais e coletivas de outros grupos culturais; a condenar concepções e práticas que conduzam à segregação e à discriminação de grupos étnicos, religiosos, sociais, sexuais, etc. (CAIMI, 2001, p. 165).

Em âmbito historiográfico, esse movimento se expressa pelo interesse em estudar e compreender outras temporalidades também a partir da pluralidade de experiências socioculturais, multiplicando-se os objetos, enfoques e problemas de pesquisa assumidos pelos historiadores, como discutiremos adiante.

Esse texto busca, então, elucidar aspectos da interface entre a produção acadêmica - especialmente a produção do campo historiográfico sobre o continente africano e sobre a escravidão negra -, as diretrizes curriculares nacionais correlatas à Lei ${ }^{\circ} 10.639 / 03$ e o ensino de história. Procura ressaltar, ainda, alguns dos desafios que se colocam hoje à prática pedagógica de professores da Educação Básica que assumem a responsabilidade de trabalhar tais conteúdos.

Para isso, traçaremos um breve panorama de alguns dos principais temas, questões e polêmicas que envolvem a produção do conhecimento sobre África e sobre presença africana e afro-descendente no Brasil. Buscaremos, ainda, algumas discussões relativas a conceitos-chave envolvidos no trato da temática, tais como os conceitos de cultura e identidade e cultura e identidade afro-brasileira, problematizando a abordagem de tais conceitos em documentos oficiais, especialmente o texto das Diretrizes Curriculares Nacionais para a Educação das Relações Étnico-raciais e para o Ensino de História e Cultura Africana e Afro-brasileira ${ }^{2}$. Discutiremos, ainda, algumas das orientações presentes neste documento, tendo como referência os debates que vêm sendo travados no âmbito do ensino de história, nas últimas décadas.

\section{Historiografia e as novas perspectivas de análise sobre África, africanos e afro- descendentes: breve panorama}

Devemos lembrar que a produção historiográfica, em nível nacional e mundial, é caracterizada por uma grande variedade de tendências e correntes de pensamento, cuja

\footnotetext{
${ }^{2}$ A elaboração e aprovação, pelo Conselho Nacional de Educação (CNE), de Diretrizes Curriculares Nacionais para a Educação das Relações Étnico-raciais e para o Ensino de História e Cultura Africana e Afro-brasileira (2004) se insere no processo de institucionalização da Lei $n^{\circ} 10.639 / 03$. Tais Diretrizes apresentam um conjunto de determinações e orientações voltadas à implementação dessa lei. Ao longo deste texto, a menção a tal documento se fará, por diversas vezes, de maneira abreviada, usando-se apenas a expressão Diretrizes Curriculares... ou ainda Diretrizes correlatas.
} 
enumeração extrapola os limites do trabalho aqui proposto. Por ora, vale ressaltar que, ao longo de nossa história, os estudos sobre a escravidão ou sobre aspectos diversos envolvendo a chamada "questão racial" vêm sendo caracterizados pela multiplicidade de tendências e por diálogos com conceitos e categorias analíticas diversos. Sobretudo nas últimas décadas, no bojo do processo de expansão dos programas de pós-graduação e do surgimento de diferentes grupos e instituições de pesquisa, novas abordagens e perspectivas de análise, abertas por diferentes movimentos de renovação historiográfica, vêm sendo incorporadas aos estudos. Percebe-se, dessa forma, maior proximidade com programas de reescrita da história africana, em âmbito mundial, assim como uma significativa ampliação e revisão dos estudos sobre escravidão e sobre diferentes facetas da presença africana e afro-descendente, em nosso país.

\section{A África "também” tem história}

Seria somente a partir de meados do Século XX, no bojo do processo de independência das antigas colônias europeias na África, que se constituiria um movimento de reescrita da história africana, sendo beneficiado pelas novas perspectivas de análise historiográfica. Tal movimento se caracterizou pelo propósito de romper com uma história da África restrita à história da dominação europeia no continente, buscando ter como referência a história do próprio continente - sem desconhecer, obviamente, suas relações com outros povos. O novo contexto político favorecia a desmontagem da concepção hegeliana, que postulara, no Século XIX: “A África não é uma parte histórica do mundo. Não tem movimentos, progressos a mostrar, movimentos históricos próprios" (HEGEL, apud ARNAUT; LOPES, 2005). A negação de uma história própria ao continente, ou a descrença na possibilidade de se escrevê-la, ainda encontrava eco nos meios acadêmicos, em meados do Século XX, como se percebe pelo exemplo do famoso professor de Oxford, "Sir Hugh Trevor-Hoper, que afirmou, em 1963, não haver uma história da África subsaariana, mas tão somente a história dos europeus no continente, porque o resto era escuridão, e a escuridão não é matéria da história." (SILVA, 2003, p. 229).

A "escuridão" a que se refere o professor de Oxford diz respeito a uma suposta ausência de fontes, especialmente as escritas, capazes de sustentar o que tradicionalmente se compreendia por produção do conhecimento histórico. Não é por acaso que um rompimento com essa perspectiva se anunciou, de forma mais marcante, 
em um momento de transformações políticas no continente, contexto no qual se tornaria possível - e legítimo - o investimento em uma (re)escrita da história da África, valendose do processo de ampliação do conceito de história e de fontes históricas, já em curso no âmbito de diferentes tendências historiográficas. Tal situação nos confirma a ideia de que a produção do conhecimento histórico, longe de obedecer a critérios puramente acadêmicos e epistemológicos, se relaciona diretamente com o contexto histórico, sendo fruto, também, dos interesses políticos, disputas e relações de poder presentes em cada momento. E o contexto sociopolítico, inaugurado com os processos de independência, favoreceu a construção de novos olhares e novos conhecimentos sobre a milenar história do continente africano. A combinação entre um contexto político favorável e o alargamento do campo da História permitiu, então, a incorporação de uma infinidade de fontes e a multiplicação das pesquisas e publicações, muitas delas elaboradas por historiadores e cientistas sociais africanos.

Tal movimento de reescrita da história africana tem sido marcado pela heterogeneidade, tanto em seus fundamentos epistemológicos quanto em suas concepções e propósitos políticos. O historiador guineense Carlos Lopes (1995) identificou a existência de três grandes momentos de interpretação histórica da África: a corrente da Inferioridade Africana; a corrente da Superioridade Africana; e os novos estudos africanos. A corrente da Inferioridade Africana, fruto de séculos de dominação e espoliação do continente, teria como importante marco teórico o paradigma hegeliano, sendo responsável por uma visão marginal da contribuição africana, “[...] de que a África não pode produzir conhecimento ou História por si só.” (p. 23). Embora ultrapassada do ponto de vista acadêmico, esta visão ainda prevalece no imaginário coletivo ocidental. Ao mesmo tempo, o autor apresenta uma visão crítica da corrente da "Superioridade Africana", por ele chamada de "pirâmide invertida", que teria partido do equivocado argumento de que "a África também tem uma História [...], em vez de apenas temos História”. Caracterizada pela perspectiva de se contrapor ao paradigma da "inferioridade", essa corrente buscou promover uma supervalorização do continente, mas acabou não conseguindo se libertar de categorias europeias, ao comparar, por exemplo, feitos históricos africanos ao que se considerava "grandioso" em outras culturas e regiões do mundo. Identificando o historiador Joseph Ki-Zerbo como um dos importantes pioneiros dessa corrente, Lopes assim avalia essa iniciativa: 
Os dados pareciam jogados. Doravante, tratava-se de escrever a História dos povos de África, longe do binômio colonizador-colonizado, afastando-se o mais possível da historiografia colonial, excepto quando esta fornecia argumentos favoráveis à superioridade Africana. É a História das interacções e dos oprimidos, mas também de uma idílica e harmoniosa sociedade précolonial. Longe de lutas de classe ou de poder, longe de hipóteses suscetíveis de pôr em causa a precariedade das evidências e metodologias. Uma História que se vai concentrar nas mudanças sociais, na contribuição Africana, na resistência ao colonialismo e no conceito de iniciativa local. (LOPES, 1995, p. 26).

Para Lopes, os historiadores da pirâmide invertida seriam responsáveis pela conquista de um importante projeto, patrocinado pela UNESCO, a partir dos anos 1960: o projeto "História Geral da África". Com objetivo de desenvolver uma ampla pesquisa sobre o continente, na perspectiva dos próprios africanos, abrangendo desde o surgimento dos primeiros seres humanos até os dias atuais, tal empreendimento resultou na publicação de oito volumes, fruto do trabalho de diversos especialistas, em grande parte africanos $^{3}$. Este projeto, ao mesmo tempo em que simbolizou a afirmação da pirâmide invertida, também possibilitou o surgimento do que Lopes chama de "novos Historiadores Africanos, libertos da necessidade de impor uma superioridade Africana" (LOPES, 1995, p. 27). O texto de Lopes, escrito em 1995, apontava para a potencialidade desta nova corrente, ainda incipiente naquele momento, frente ao desafio de buscar a complexidade das historicidades africanas.

De fato, nas últimas décadas, muito se avançou na produção historiográfica sobre o continente africano. Inúmeras obras vêm surgindo no cenário internacional e nacional, sendo já significativa a quantidade de publicações acessíveis ao público brasileiro. Também foram criadas, neste período, diversas revistas especializadas em África, favorecendo a maior divulgação de pesquisas e contribuindo para a consolidação da história da África como disciplina acadêmica. Nas palavras de Silva (2003, p. 236): “A história da África alcançara a maioridade nos meios intelectuais e universitários africanos, europeus e norte-americanos." O mesmo autor lamenta que movimento de

\footnotetext{
${ }^{3}$ No Brasil, só recentemente a obra completa foi traduzida para o português, em tarefa assumida pelo Núcleo de Estudos Afro-Brasileiros (NEAB), da Universidade Federal de São Carlos (UFSCar), através de parceria estabelecida com o Ministério da Educação e a UNESCO. Tal projeto também incluiu a disponibilização dos oito volumes nas páginas eletrônicas do MEC, da UNESCO e da UFSCar, além de sua distribuição para bibliotecas públicas do País.
} 
tamanha magnitude não tenha ocorrido no Brasil, ${ }^{4}$ ressaltando o quanto a compreensão de nossa história passa, indubitavelmente, pelo conhecimento da história africana.

Mas, apesar de incipiente, o interesse pela história da África já atinge um considerável grupo de pesquisadores brasileiros, responsáveis pela realização de congressos e eventos diversos, pela publicação de obras e pela organização de centros de pesquisa (OLIVA, 2008) ${ }^{5}$. De acordo com Silva (2003), é difícil, em nosso país, delimitar rigidamente as fronteiras que separam uma história da África de uma parte importante da história do Brasil, sendo muitas vezes impertinente pensar uma história da África que não inclua suas relações com o Brasil e uma história da presença africana no Brasil que não remeta à aspectos diversos da história do continente africano. Oliva (2008, p. 44), no entanto, enfatiza a “[...] necessidade de dinamizar os estudos da África e desvinculá-los daqueles ligados às temáticas afro-brasileiras, para percebê-los em seu próprio eixo histórico africano ou naquilo que é chamado de contexto ou Mundo Atlântico".

De toda forma, não se pode negar que tem crescido, em nosso país, nos últimos anos, o interesse pelos estudos sobre África, para além daqueles que, durante muito tempo, se restringiram ao interesse quase exclusivo pelo tráfico negreiro. Além da ampliação de pesquisas, a história da África vem adquirindo status de disciplina acadêmica e começa a ser introduzida nos currículos de diversos cursos de graduação em História, embora trate-se de um processo ainda incipiente.

Mas, ainda que venhamos assistindo a uma ampliação da produção historiográfica sobre a África e sua crescente introdução nos currículos das graduações em História, em nosso país, a grande maioria dos professores que lecionam essa disciplina nas escolas de Educação Básica brasileiras não tiveram - ou tiveram muito pouco - acesso a conhecimentos específicos sobre a história do continente africano, em sua formação inicial, inclusive aqueles que se graduaram em História. Mesmo que tais conteúdos venham comparecendo de forma mais sistemática em cursos de formação continuada, prevalece, entre os professores, o pouco acesso a tais conhecimentos,

\footnotetext{
${ }^{4}$ Silva reconhece, no entanto, as honrosas exceções a esse descaso com a história africana, por parte de pesquisadores brasileiros, e enumera alguns de seus pioneiros, entre os quais Nina Rodrigues, Pierre Verger, Antonio Olinto, Manuela e Mariano Carneiro da Cunha, e o célebre Gilberto Freyre, entre outros.

${ }^{5}$ Vale destacar a criação de alguns centros de estudos acadêmicos, como o pioneiro Centro de Estudos Afro-Orientais (CEAO), criado em 1959, na Universidade Federal da Bahia; o Centro de Estudos Africanos (CEA), da Universidade de São Paulo, originalmente criado em 1965, sob denominação de Centro de Estudos e cultura africana; e ainda o Centro de Estudos Afro-Asiático (CEAA), criado em 1973, na Universidade Cândido Mendes. Cada um desses centros publica uma revista, respectivamente denominadas Afro-Ásia; África e Estudos Afro-Asiático.
} 
dificultando, assim, sua introdução como conteúdo curricular obrigatório. Por causa disso, também, muitos professores não conseguem, em suas aulas, ir além das imagens estereotipadas e homogeneizadoras do continente africano, reproduzindo um senso comum que restringe a África às imagens de guerras, pobreza, fome e doenças. Por outro lado, a necessidade de romper com tais representações também tem levado muitos professores a buscar somente imagens positivas e valorizadoras da história e cultura africanas. Este movimento parece reproduzir, no contexto escolar, algo semelhante ao que o historiador Carlos Lopes identificou em relação às correntes historiográficas que tendem a inferiorizar ou que, ao contrário, buscam afirmar a superioridade africana. De toda forma, as abordagens sobre o continente africano que têm prevalecido em inúmeras escolas de educação básica expressam uma dificuldade de acesso a elementos e dados históricos capazes de fazer emergir a complexidade e a diversidade de situações sóciohistóricas presentes no continente, em diferentes épocas.

Os livros didáticos, materiais largamente utilizados na educação escolar brasileira e, dessa forma, uma das leituras mais acessíveis aos professores de diferentes partes do Brasil, ainda apresentam lacunas e fragilidades na abordagem do continente, conforme mostra pesquisa desenvolvida por Oliva, que nos diz:

\footnotetext{
Silêncio, desconhecimento e poucas experiências positivas. Poderíamos assim definir o entendimento e a abordagem da história africana nas coleções de livros didáticos brasileiros. Apenas um número muito pequeno de manuais possui capítulos específicos sobre a temática. Nas outras obras, a África aparece apenas como um figurante que passa despercebido em cena, sendo mencionada como um apêndice misterioso e pouco interessante de outros assuntos. (OLIVA, 2008, p. 31).
}

\section{Múltiplos olhares sobre a escravidão e a presença africana no Brasil}

Se, por um lado, podemos considerar ainda incipiente a produção brasileira sobre África ou sobre as relações Brasil-África, por outro lado, podemos dizer que os estudos sobre a presença africana no Brasil possuam já uma longa trajetória, tendo crescido, significativamente, nessas últimas décadas.

Entre os temas mais pesquisados pelos historiadores, a escravidão negra aparece em primeiro lugar, podendo-se identificar diferentes tendências na trajetória da produção nacional e internacional sobre o tema.

O primeiro conjunto de análises sobre a população negra, no Brasil, não por acaso, surgiu no momento de transição do trabalho escravo para o trabalho livre, em 
meio à repercussão das ideias e teorias do chamado "racismo científico", do Século XIX. Assentada em falsos pressupostos, a produção intelectual brasileira de fins do Século XIX e primeiras décadas do XX, embora diversa, e até divergente em alguns aspectos, tinha em comum a tese de inferioridade do negro e sua consequente contribuição negativa para a formação do povo brasileiro. (QUEIRÓZ, 1998, p. 104). Ainda assim, trouxe contribuições pioneiras para os estudos sobre os africanos e seus descendentes. Uma importante vertente de análise sobre a escravidão e sobre a população negra se consolidaria nos anos 1930, sobretudo a partir dos estudos de Gilberto Freyre, Donald Pierson e Thales de Azevedo. Obra emblemática dessa nova vertente, Casa Grande \& Senzala apresenta uma análise pautada na concepção de uma sociedade de tipo paternalista, baseada em relações de caráter pessoal, na qual teria predominado uma maior empatia entre as raças e uma relação senhor-escravo mais branda e menos violenta. A intensa miscigenação presente na sociedade brasileira foi usada por Freyre como um dos principais argumentos para cunhar a ideia de "democracia racial", que se transformaria na grande matriz teórica de explicação das relações raciais brasileiras, até pelo menos meados do Século XX. De acordo com Queiróz (1998), a obra de Freyre inauguraria uma grande polêmica historiográfica sobre a caracterização do sistema escravista brasileiro: mais brando e benevolente, como defendia Freyre, ou tão violento e cruel como em qualquer outro país que vivera a experiência da escravidão, como passaram a defender os primeiros críticos de Freyre. A obra de Freyre teve grande repercussão nos cenários nacional e internacional, instigando diversos pesquisadores, no Brasil e em diferentes partes do mundo, a se interessarem pelo tema da escravidão nas Américas.

Mas foi no período pós-guerra, em um contexto mundial marcado pela derrota do nazismo, pela intensificação das lutas dos negros norte-americanos pela igualdade racial e direitos civis, e por todo um movimento mundial de combate às ideologias racistas, capitaneado pela recém-criada UNESCO, que se intensificaram os estudos sobre a escravidão negra. Uma nova geração de historiadores norte-americanos passou a defender a tese de que as peculiaridades do escravismo nas diferentes épocas e regiões da América eram pouco significativas frente à manutenção de padrões comuns, inexistindo um sistema mais brando que outro.

No Brasil, sob influência de tais ideias e em meio à intensa efervescência política e social, uma nova corrente de interpretação histórica emergiu, nos anos 1950. Autores como Florestan Fernandes, Roger Bastide, Otávio Ianni, Emília Viotti e 
Fernando Henrique Cardoso, muitos deles envolvidos em projetos de pesquisa sobre as relações raciais brasileiras, combateram as ideias de Freyre e enfatizaram o caráter violento e cruel da relação escravista aqui estabelecida, marcada por coerção e intensa repressão e que resultaria, de acordo com alguns desses pesquisadores, em um processo de "coisificação subjetiva" do cativo (QUEIRÓZ, 1998). Essa vertente de análise, centrada no "[...] enfoque sociológico das relações sociais e na discussão da natureza capitalista da economia escravista [...]" (SOUZA, 1989, p. 134), foi marcada pela incorporação de conceitos e esquemas interpretativos de base marxista, tendência que se manteve hegemônica ao longo das décadas de 1960 e $1970^{6}$. Nesta última, uma nova geração de "historiadores revisionistas" continuaria a debater - e se opor - às ideias de Freyre, entre eles, Jacob Gorender, que em seu já clássico "Escravismo Colonial" (1978), trabalhou com a ideia de um "modo de produção escravista colonial", no qual violência e coerção são consideradas marcas intrínsecas do sistema ${ }^{7}$. E ainda Clóvis Moura, um dos primeiros historiadores a se debruçar sobre rebeliões escravas do Século XIX, na Bahia.

A década de 1980 seria uma das mais profícuas em termos de ampliação e renovação da historiografia brasileira sobre escravidão negra, em um cenário marcado pelo crescimento da pós-graduação e por intensa mobilização social. As novas formas de luta e atuação política que emergiram na sociedade, naquele momento, contribuíram para aguçar o interesse dos cientistas sociais, em geral, e dos historiadores, em particular, pela história do trabalho e dos trabalhadores, em diferentes épocas, em abordagens que já não se limitavam às relações de produção, mas passaram a incluir os movimentos de resistência, a produção cultural e as vivências cotidianas de diferentes sujeitos históricos, em suas relações familiares, religiosas, no lazer, nas negociações e conflitos do dia a dia.

Foi nesse contexto que emergiram as novas leituras sobre a escravidão brasileira, muitas delas "valendo-se da história das mentalidades e do cotidiano, atrelando-se, portanto, às linhas mestras que definem a historiografia contemporânea" (SOUZA,

\footnotetext{
${ }^{6}$ Exemplo disso pode ser encontrado na clássica obra de Florestan Fernandes, A integração do negro na sociedade de classes, publicada pela Dominus Editora, em 1965, em dois volumes. O título do livro, assim como de alguns de seus capítulos, nos dão pistas da vertente de análise assumida pelo autor, quando trata, por exemplo, de "O negro na emergência da sociedade de classes", "O negro e a revolução burguesa", Expansão urbana e desajustamento estrutural do negro", entre outros.

${ }^{7}$ Ao lado de Gorender, autores como Ciro Flamarion Cardoso e Fernando Novais também se debruçaram sobre a compreensão do escravismo colonial como um modo de produção específico, debatendo sobre a natureza capitalista ou não da escravidão (SOUZA, 1989).
} 
1989, p. 135), sendo fortemente influenciadas por autores como o historiador inglês E. P. Thompson, e ainda pela obra de Michel Foucault, sobretudo Vigiar e Punir. Conceitos como os de "experiência social" e de "cultura", e uma análise voltada à complexidade das "relações de poder" no âmbito do sistema escravista, permitiram a construção de novos olhares e a busca de novas fontes, levando historiadores de diferentes partes do Brasil a vasculharem os mais variados tipos de arquivos e fontes documentais, a ampliarem o leque de temáticas e abordagens e estenderem suas pesquisas para além dos locais onde se desenvolveram os grandes sistemas de exploração da mão de obra escrava, levando a uma crescente regionalização dos estudos sobre escravidão, no Brasil (SOUZA, 1989; FLORENTINO, 2006).

Uma das obras pioneiras dessa nova perspectiva de análise foi Ser escravo no Brasil, de Kátia Mattoso, publicada em 1982. Além dessa, inúmeras obras surgiram ao longo dos anos 1980, podendo-se citar, a título de exemplos: Ideologia e escravidão. Os letrados e a sociedade do Brasil colonial, de Ronaldo Vainfas (1986), que analisa a produção de letrados do período colonial acerca da escravidão, procurando identificar o discurso ideológico presente nos escritos de homens que pensaram o escravismo entre o final do Século XVII e o final do XVIII; Campos da violência, de Silvia Lara (1988), em que analisa processos judiciais de Campos dos Goitacazes, RJ, para o período 17501808; O feitor ausente: estudo sobre a escravidão urbana no Rio de Janeiro, de Leila Algranti (1988), um dos primeiros estudos sobre escravidão urbana e que contribui para desmistificar a ideia de que esta teria sido mais branda ou constituiria uma fissura no sistema escravista; Visões da Liberdade, de Sidney Chalhoub (1990), em que analisa processos criminais e de obtenção de alforria, na cidade do Rio de Janeiro, nas últimas décadas da escravidão.

Além desses, inúmeros outros estudos, quase sempre apoiados em rigorosa pesquisa empírica, buscaram desvendar as várias faces da relação senhor-escravo, procurando reconhecer as muitas formas de "resistência-acomodação" vivenciadas no âmbito do escravismo, abordando a experiência negra a partir de múltiplas dimensões e reconhecendo seu papel como agentes políticos capazes de negociar melhores condições de vida e trabalho (SOUZA, 1989; QUEIRÓZ, 1998). Entre as obras que se dedicaram a compreender os "espaços de negociação" presentes na relação senhor-escravo poderia se destacar Negociação e conflito: a resistência negra no Brasil escravista, de João José Reis e Eduardo Silva, publicada em 1989. O capítulo intitulado "Entre Zumbi e Pai João, o escravo que negocia", de Eduardo Silva, se contrapõe tanto às análises que 
enfatizaram o caráter brando e paternalista da escravidão, cuja figura emblemática seria a de "Pai João", personificação do escravo submisso e conformado, quanto às análises que reduziram as formas de resistência escrava à figura heróica de Zumbi, símbolo da luta contra uma escravidão violenta. Entre os dois extremos, os autores identificam uma infinidade de formas de negociação e procuram mostrar que "os escravos não foram vítimas nem heróis o tempo todo." A obra tornou-se emblemática de uma nova vertente de análise e, de acordo com Abreu (2004, p. 236), “A expressão 'Entre Zumbi e Pai João` consagrou-se como uma máxima para exprimir a ideia de uma luta cotidiana contra a escravidão."

Tal perspectiva também foi alvo de críticas e chegou a ser classificada, por Gorender $^{8}$, como "neopatriarcalista" (QUEIRÓZ, 1998), para se ter uma ideia dos dissensos historiográficos em torno da escravidão, nestas últimas décadas.

Em recente balanço da historiografia da escravidão no Brasil ${ }^{9}$, Florentino (2006) avalia o avanço das pesquisas desde o momento de comemoração do centenário da abolição, em $1988^{10}$, Segundo o autor, nestas duas últimas décadas, a quantidade de programas de pós-graduação no Brasil multiplicou-se por cinco, resultando em uma significativa expansão da produção de pesquisas históricas. Embora a produção sobre escravidão não tenha crescido na mesma proporção, Florentino (2006) reconhece os avanços, sobretudo no que se refere à diversificação de temas. De acordo com ele:

\begin{abstract}
Hoje em dia já não soam tão estranhos estudos sobre a família escrava (tida antes como aspecto ancilar da história colonial), as irmandades negras, os mecanismos e padrões de alforrias, etnicidade, formas de controle social e de resistência, tráfico interno e externo de escravos, para não falar nos trabalhos acerca do negro no imediato pós-abolição. Melhor: são temas encampados por profissionais das mais diversas tendências teórico-metodológicas, embora não se possa dizer o mesmo do ponto de vista estritamente ideológico - já não viceja entre nós, por exemplo, o menor traço de uma historiografia, digamos, liberal, da escravidão. (FLORENTINO, 2006).
\end{abstract}

Esse processo de expansão e diversificação de temas e abordagens se estendeu também aos estudos sobre descendentes de escravos, ampliando-se as pesquisas que buscam compreender a situação de marginalidade social vivenciada pela população afro-descendente, envolvendo pesquisadores de diferentes áreas do campo das Ciências

\footnotetext{
${ }^{8}$ Ver a esse respeito, A escravidão reabilitada, de Jacob Gorender.

${ }^{9}$ Referimo-nos ao texto de "Introdução" do número 52 da Revista Brasileira de História, que trouxe um dossiê sobre escravidão.

${ }^{10}$ Naquela ocasião, outro número da Revista Brasileira de História também apresentara um dossiê sobre escravidão.
} 
Sociais. Muitos desses estudos, partindo do mapeamento da situação sócio-econômica da população afro-descendente, têm ajudado a melhor compreender a configuração histórica e especificidades do racismo brasileiro, trazendo novas contribuições para o questionamento e desmontagem do mito da "democracia racial"

O breve levantamento aqui apresentado, longe de pretender esgotar a produção historiográfica e das Ciências Sociais acerca do continente africano e da escravidão brasileira, procurou apenas situar a complexidade e a variedade de temas, questões, conceitos, aportes teóricos, polêmicas e dissensos que têm configurado a produção acadêmica em torno dessas temáticas. Tal levantamento nos dá uma ideia do que "bate à porta" dos currículos escolares, neste momento. Quando apontamos o "desconhecimento" dos professores sobre a temática - situação diagnosticada pelos próprios docentes - poderíamos inverter os polos dessa questão, e pensar: o que seria “conhecer essa questão"? Ou seja, quais conhecimentos, afinal, se espera dos professores? Levando em conta a amplitude dos conhecimentos que vêm sendo produzidos e as múltiplas problemáticas que suscitam - e tendo em vista que os currículos são sempre fruto de uma seleção -, quais conhecimentos deveriam fazer parte dos currículos de formação docente? Ou, para usar a expressão de Shulman (2001), o que seria uma "base de conhecimentos" para o ensino de história e cultura africana e afro-brasileira?

Ainda que não seja possível responder a todas essas questões, pode-se identificar alguns dos temas e questões que vêm se apresentando como "pontos de tensão" ou vêm sendo percebidos, pelos professores, como grandes lacunas em sua formação. A história africana, por exemplo, tem se apresentado como uma das principais interrogações, um dos conteúdos em que os professores se sentem mais desamparados. Não por acaso, trata-se de um campo de pesquisas relativamente novo, em que a divulgação de pesquisas, em nosso país, ainda é restrita, dificultando o acesso dos professores a essa produção de conhecimento.

Por outro lado, a escravidão brasileira também emerge como uma questão que merece ser problematizada pelas múltiplas abordagens que permite, pelos dilemas que suscita - trabalhar ou não? Em que momento do currículo? -, pelos próprios

\footnotetext{
${ }^{11}$ Entre alguns dos pesquisadores que têm se dedicado a estudos sobre a população afro-descendente, culturas afro-brasileiras e sobre as especificidades da questão racial, em nosso país, poderíamos citar, a título de exemplo - e cientes das muitas omissões desta breve lista - Antonio Sérgio Guimarães, Edson Borges, Eliane Cavalleiro, Hebe Mattos, Kabengele Munanga, Letícia Vidor Reis, Lilia Schwarcz, Luis Alberto Oliveira Gonçalves, Martha Abreu, Nilma Lino Gomes, Petronilha Gonçalves, Regina Pahim Pinto e muitos outros.
} 
significados que se constroem quando a ênfase recai sob a perspectiva de positivação da história africana e afro-brasileira - afinal, o que haveria de "positivo" na escravidão? A resistência escrava, simbolizada na figura de Zumbi, poderia ocupar esse lugar de positivação/positividade, conforme a aposta de diversos docentes? Um maior domínio das principais questões que configuram a produção do conhecimento sobre escravidão, incluindo a grande polêmica historiográfica em torno de sua caracterização, poderia ajudar os professores a melhor fundamentarem suas escolhas, ou mesmo encontrar outras alternativas que não se resumam à polarização entre "incluir ou excluir esse tema do currículo"? Neste aspecto, podemos recorrer a Lopes (1999), que nos adverte sobre a necessidade de também considerar critérios epistemológicos no momento de se decidir o que é fundamental de ser ensinado nas escolas. Quando a autora nos alerta sobre a necessidade de admitir que alguns saberes são mais fundamentais do que outros, em função do desenvolvimento histórico do conhecimento e em função do modelo de sociedade que desejamos, e enfatiza a necessidade de considerar a importância que o próprio conteúdo já assumiu historicamente, nos parece trazer algumas pistas para se pensar sobre a importância da temática da escravidão no âmbito dos estudos históricos e, assim, melhor compreender o significado de existir uma polêmica - detectada entre os professores pesquisados - sobre trabalhar ou não este tema.

Além do mais, se concordamos que esse movimento de reescrita da história brasileira, a partir das contribuições dos povos africanos e seus descendentes, pode se transformar em referência e fonte de estudos para diferentes instâncias e sujeitos de alguma forma envolvidos com a educação escolar, num movimento de aproximação entre o mundo acadêmico e a educação básica, não podemos desconsiderar inúmeros outros saberes e práticas que também participam da constituição dos saberes escolares e docentes. Dos professores que se responsabilizarão por transformar alguns desses conhecimentos em saberes escolares, espera-se - e exige-se - muito mais. Partindo do pressuposto de que o conhecimento escolar é um amálgama constituído por saberes de diferentes naturezas, e que se realiza em estreito diálogo com a cultura escolar, quais outros conhecimentos, oriundos de quais campos e instâncias - incluindo os saberes da experiência - os professores também precisam mobilizar, para dar conta da tarefa que se lhes apresenta nesse momento? Vale a pena prosseguirmos na tarefa de mapear temas e conceitos que se têm se apresentado como importantes referências para o ensino de história e cultura africana e afro-brasileira, tanto em suas orientações oficiais quanto no currículo em ação. 


\section{Culturas afro-brasileiras e identidade negra: problematizando conceitos e} Dialogando com orientações das "Diretrizes Curriculares Nacionais para a Educação das Relações Étnico-raciais e para o Ensino de História e Cultura Africana e Afro-brasileira"

Os conceitos de "cultura" e "identidade" têm se apresentado como estratégicos e fundamentais à implementação da Lei $\mathrm{n}^{\circ}$ 10.639/03. Inúmeros professores, ao assumirem o desafio de promover uma educação das relações étnico-raciais, enfrentando práticas racistas identificadas no contexto escolar e suas consequências negativas para a autoestima e rendimento escolar de alunos e alunas negros, se deparam com a necessidade, primeira, de promover um reconhecimento e positivação da identidade negra. Para muitos deles, o caminho para isso tem passado pelo estudo das chamadas "culturas afro-brasileiras", também numa perspectiva positivada. O processo em curso vai além da inclusão de novos conteúdos como componentes curriculares obrigatórios. Trata-se de um projeto político de maior amplitude, que se insere em um programa das chamadas "políticas afirmativas". Legitimada no plano da ação política voltada à construção de uma sociedade mais equânime e democrática, a abordagem da história e cultura africana e afro-brasileira pelo viés da positivação apresenta-se, no entanto, como mais um elemento de complexidade do processo em curso.

Assim, reconhecendo a importância do surgimento de uma lei que se destina a promover a reeducação das relações étnico-raciais, assim como a potencialidade das orientações contidas em suas "Diretrizes" correlatas, necessitamos desenvolver um olhar mais cuidadoso para essa legislação, com intuito de ampliar a compreensão de alguns dos desafios e riscos que se colocam em seu processo de recepção.

Essa análise inclui, em primeiro lugar, uma ponderação sobre os limites que qualquer texto - oficial ou não - apresenta, quando se propõe a sintetizar reivindicações históricas e assumir o enfrentamento de questões socialmente problemáticas, a partir de prescrições, normatizações e orientações de trabalho. No caso de um documento oficial, construído em um ambiente supostamente democrático de negociações e disputas entre diferentes concepções e projetos de sociedade, essa tensão é ainda mais evidente. Assim, devemos compreender a emergência da Lei $\mathrm{n}^{\circ} 10.639 / 03$ e suas Diretrizes correlatas como expressão de alguns dos dilemas e embates que se fizeram - e se fazem - presentes no debate nacional e, inclusive, no seio dos próprios movimentos negros mobilizados em torno de sua elaboração. 
Para além dessa percepção, torna-se fundamental, ainda, problematizar algumas das concepções e marcos conceituais incorporados ao texto das Diretrizes Curriculares..., dentro do pressuposto de que esses se tornam importantes balizas para políticas públicas empreendidas por sistemas de ensino e para a construção e reconstrução de saberes e práticas docentes.

Tendo em vista que os conceitos de identidade e cultura também ganham especial atenção no texto das Diretrizes Curriculares..., nos dedicamos a problematizar as concepções de cultura e identidade afro-brasileira - ou negra - presentes nesse documento. Para isso, será necessário recorrer a alguns estudos e discussões que têm se debruçado sobre as chamadas "culturas afro-brasileiras", destacando-se a vertente que rejeita a perspectiva de encontrar as "origens" africanas das culturas negras do continente americano, e se volta para os intercâmbios culturais, buscando compreender sua multidirecionalidade e dinamicidade, assim como as hierarquias e as relações de poder aí envolvidas.

Além disso, também buscaremos problematizar algumas das prescrições e orientações contidas no texto das Diretrizes Curriculares..., a partir de referências que vêm sendo construídas e debatidas no campo do ensino de História.

Frequentemente confundidos ou associados de forma direta e mecânica (a uma cultura corresponderia uma identidade), os conceitos de cultura e identidade têm sido problematizados no campo das ciências humanas e sociais, ressaltando-se a necessidade de distinção entre os dois, sobretudo quando se fala em "identidades culturais". De acordo com Cuche,

\begin{abstract}
Não se pode, pura e simplesmente confundir as noções de cultura e de identidade cultural ainda que as duas tenham uma grande ligação. Em última instância, a cultura pode existir sem consciência de identidades, ao passo que as estratégias de identidade podem manipular e até modificar uma cultura que não terá então quase nada em comum com o que ela era anteriormente. A cultura depende em grande parte de processos inconscientes. A identidade remete a uma norma de vinculação, necessariamente consciente, baseada em oposições simbólicas. (CUCHE, 2002, p. 176).
\end{abstract}

Não é objetivo deste trabalho fazer uma exaustiva discussão destes conceitos, mas vale pensar como eles têm sido (re)apropriados e (re)significados na arena social, quando está em jogo a discussão sobre cultura e identidade afro-brasileira ou cultura e identidade negra. Não por acaso, eles se tornam estratégicos na agenda política dos movimentos negros, como defende Guimarães: 
As novas formas culturais do movimento negro na América Latina e no Brasil [...] têm enfatizado o processo de re-identificação dos negros, em termos étnico-culturais. Ao que parece, só um discurso racialista de autodefesa pode recuperar o sentimento de dignidade, de orgulho e de autoconfiança, que foi corrompido por séculos de racialismo universalista e ilustrado. O ressurgimento étnico é, quase sempre, amparado nas ideias gêmeas de uma terra a ser recuperada (o território dos antigos quilombos; ou a transformação, largamente simbólica, de quarteirões urbanos empobrecidos em comunidades ou "quilombos" negros), e de uma cultura a redimir e repurificar, no contato com uma África imaginária, a África trazida e mantida como memória. (GUIMARÃES, 2005, p. 61).

\section{Identidades em questão: estratégias e riscos}

A perspectiva de positivação da identidade negra, como estratégia para "recuperar o sentimento de dignidade, de orgulho e de autoconfiança" e a valorização de uma cultura "a redimir e repurificar" tem orientado muitas das práticas e programas de combate ao racismo, fazendo-se presente também no texto das Diretrizes Curriculares... Buscando se contrapor às perversas consequências que o ideal do branqueamento e o mito da democracia racial trouxeram para a construção de identidades negras ou afrobrasileiras, as Diretrizes Curriculares... assumem uma clara opção política de constituição e valorização de uma identidade negra brasileira, a qual se faz, no corpo do texto, muitas vezes em contraponto a uma identidade branca.

Exaustivas discussões no campo das ciências sociais convergem para a seguinte perspectiva, sistematizada por Cuche (2002, p. 182): “[...] a identidade é uma construção que se elabora em uma relação que opõe um grupo aos outros grupos com os quais está em contato [...]" e por isso "[...] a identidade existe sempre em relação a uma outra." Ainda que partindo de tal premissa, torna-se importante problematizar a referência a uma identidade negra - de matriz africana - em oposição a uma identidade branca - de matriz europeia -, na forma bipolarizada e muitas vezes essencializada que transparece no texto das Diretrizes Curriculares... Ainda de acordo com Cuche, aqueles que concebem a cultura como

[...] uma "segunda natureza", que recebemos como herança e da qual não podemos escapar, concebem a identidade como um dado que definiria de uma vez por todas o indivíduo e que o marcaria de maneira quase indelével. Nesta perspectiva, a identidade cultural remeteria necessariamente ao grupo original de vinculação do indivíduo. A origem, as "raízes" segundo a imagem comum, seriam o fundamento de toda identidade cultural, isto é, aquilo que definiria o indivíduo de maneira autêntica. [...] Vista desta maneira, a identidade é uma essência impossibilitada de evoluir e sobre a qual o indivíduo ou o grupo não tem nenhuma influência. (CUCHE, 2002, p. 178). 
Mesmo que o texto das Diretrizes Curriculares... aponte que "ser negro no Brasil não se limita às características físicas. Trata-se de uma escolha política. Por isso, o é quem assim se define." Ou ainda que ressalte a "complexidade que envolve o processo de construção da identidade negra em nosso país", apontando as múltiplas possibilidades de identificação colocadas e a importância da autoidentificação, recorrese frequentemente aos termos "negros" e "brancos" "[...] como expressões claramente distintas e bem definidas, eficazes para classificar a totalidade da população brasileira". (MATTOS; ABREU, 2006, p. 53).

Com isso, as Diretrizes Curriculares... dão pouca evidência ao fato de que os amplos processos de miscigenação e trocas culturais vivenciados pela sociedade brasileira contribuíram para tornar difusas - e confusas - as fronteiras étnico-raciais, em nosso país. Ainda que a mestiçagem tenha sido usada como forma de escamotear as desigualdades raciais e dificultar a emergência de identidades negras, principalmente através do poderoso mito da democracia racial, não se pode supor que as múltiplas formas de identidade que não se enquadram nos polos "negro" ou "branco" sejam fruto de uma mera negação da identidade negra e, consequentemente, de perpetuação de uma das características do chamado "racismo à brasileira". A esse respeito, vale atentar para as provocações de Hermano Viana (2004), quando nos diz:

[...] criamos o mito de que para combater o nosso racismo devemos, entre outras coisas, deixar de valorizar o fato de sermos um povo mestiço. [...] Aquela coisa do bebê e da água do banho: para se livrar do mito da democracia racial jogamos fora a valorização da mestiçagem. (VIANNA, 2004, p. 5).

"Não jogar fora o bebê junto com a água do banho", na proposta de Viana, parece representar a possibilidade de trilhar um caminho diferenciado, em que se reconheça e assuma a pluralidade étnico-racial brasileira, sem diluir todas as possibilidades identitárias em uma identidade mestiça homogênea e tributária dos ideais de branqueamento que tanto contribuíram para a negação da identidade negra. Equacionar a possibilidade de emergência de identidades negras, compreendida como importante estratégia de combate ao racismo, com o reconhecimento das múltiplas possibilidades de identificação étnico-racial, escapando ao modelo bipolarizado, parece ser um dos grandes desafios apontado por alguns críticos das Diretrizes Curriculares... A esse respeito, Pereira nos diz que: 
[...] embora seja uma forma legítima de politização do racismo à brasileira e um recurso eficaz para o encaminhamento de agendas públicas, a negritude, tal como assumida pelo texto em análise das "Diretrizes", pode favorecer a tradução da arena racial como um cenário de bipolarização simples, com desdobramentos significativos para a ação docente e para o ensino de história em particular. [...] Sem negar a força simbólica e política dessa bipolarização, e mesmo suas razões e seus fundamentos, num contexto de luta legítima por afirmação de direitos, ressaltamos os riscos de um ensino de história que faça dela - e somente dela - a chave de interpretação da história do Brasil e das formas contemporâneas assumidas pelas relações étnico-raciais. (PEREIRA, 2008, p. 33).

Discutindo um contexto mais amplo de afirmação da negritude, em estreito diálogo com o movimento do pan-africanismo, o filósofo Kwame Appiah (1997) também nos adverte sobre os riscos do apelo ao conceito de raça, mesmo que numa perspectiva social, contribuir para um congelamento, fixação, essencialização e homogeneização de uma identidade negra.

\begin{abstract}
A "raça" nos incapacita porque propõe como base para a ação comum a ilusão de que as pessoas negras (e brancas e amarelas) são fundamentalmente aliadas por natureza e, portanto, sem esforço; ela nos deixa despreparados, por conseguinte, para lidar com os conflitos "intra-raciais" que nascem das situações muito diferentes dos negros (e brancos e amarelos) nas diversas partes da economia e do mundo. (APPIAH, 1997, p. 245).
\end{abstract}

As advertências de Appiah em relação ao conceito de raça - um constructo que está nas bases do racismo - nos ajudam a pensar sobre a armadilha da promessa ilusória, diga-se - de uma aliança e uma solidariedade "inatas", ofuscando e desconsiderando, assim, as diferenças e os conflitos entre indivíduos e grupos de uma mesma raça. Poderíamos nos perguntar se a tentativa de excluir ou silenciar as diferenças no interior de uma suposta "raça" não se mostraria tão homogeneizante e autoritária quanto a ideia de uma "identidade nacional" que se buscou impor com o surgimento dos estados nacionais modernos.

O autor não deixa de reconhecer o papel político que o movimento do panafricanismo vem cumprindo e de como a própria ideia de "pessoa negra" pode atuar como elemento catalizador de solidariedades entre africanos e entre estes e os descendentes de africanos da diáspora, em diferentes partes do mundo. Mas se mostra cético em relação a este caminho, ressaltando que a unidade africana e a identidade africana precisam de bases mais seguras do que a raça (APPIAH, 1997).

Stuart Hall é outro crítico contumaz das perspectivas de essencialização das identidades raciais, desconfiando, inclusive, de sua perspectiva libertadora: 
Não existe garantia, quando procuramos uma identidade racial essencializada da qual pensamos estar seguros, de que esta sempre será mutuamente libertadora e progressista em todas as outras dimensões. Entretanto, existe sim uma política pela qual vale lutar. Mas a invocação de uma experiência negra garantida por trás dela não produzirá essa política. (HALL, 2003, p. 347).

A relação entre plataforma política e processo de constituição de identidades reforça a compreensão do caráter multidimensional, dinâmico e flexível das identidades. "A identidade conhece variações, presta-se a reformulações e até a manipulações" (CUCHE, 2002, p. 196). O conceito de "estratégia de identidade" é retomado pelo autor para enfatizar o quanto os atores sociais também manipulam suas identidades em função de interesses e objetivos a atingir.

Na medida em que ela é um motivo de lutas sociais de classificação que buscam a reprodução ou a reviravolta das relações de dominação, a identidade se constrói através das estratégias dos atores sociais. [mas também] não é possível aos grupos e aos indivíduos fazer o que quer que desejem em matéria de identidade: a identidade é sempre a resultante da identificação imposta pelos outros e da que o grupo ou o indivíduo afirma por si mesmo. (CUCHE, 2002, p. 196).

Um dos aspectos importantes relativos à identidade negra, sobretudo na realidade brasileira, em que o fenótipo é elemento central de identificação e discriminação racial, diz respeito à dimensão corporal. Sobre esta dimensão, Gomes (2003) nos lembra que:

O corpo localiza-se em um terreno social conflitivo, uma vez que é tocado pela esfera da subjetividade. Ao longo da história, o corpo se tornou um emblema étnico e sua manipulação tornou-se uma característica cultural marcante para diferentes povos. Ele é um símbolo explorado nas relações de poder e de dominação para classificar e hierarquizar grupos diferentes. $\mathrm{O}$ corpo é uma linguagem e a cultura escolheu algumas de suas partes como principais veículos de comunicação. O cabelo é uma delas. (GOMES, 2003, p. 174).

Considerando as ponderações de Gomes e a ideia expressa por Cuche, de que a identidade é sempre a resultante da identificação imposta pelos outros e da que o grupo ou o indivíduo afirma por si mesmo (CUCHE, 2002), podemos ressaltar o fato de que "ser negro" no Brasil é também resultado dessa "identificação imposta pelo outro", a partir de um olhar que incide sobre as características físicas, numa perspectiva quase sempre desqualificadora operada pelo ideal de branqueamento. 
Se, no âmbito do racismo brasileiro, o corpo negro tem sido alvo de grande investimento pejorativo, não por acaso, os movimentos de combate ao racismo pelo viés da afirmação da identidade negra também têm colocado ênfase na estética corporal, voltando-se à afirmação da beleza negra e à valorização de elementos estéticos que remetem à ancestralidade africana. Refletindo sobre as possibilidades de abordagem desses aspectos em práticas de educação anti-racista, Gomes nos diz:

\begin{abstract}
O entendimento da simbologia do corpo negro e dos sentidos da manipulação de suas diferentes partes, entre elas, o cabelo, pode ser um dos caminhos para a compreensão da identidade negra em nossa sociedade. Pode ser, também, um importante aspecto do trabalho com a questão racial na escola que passa despercebido pelos educadores e educadoras. Em torno da manipulação do corpo e do cabelo do negro existe uma vasta história. Uma história ancestral e uma memória. Há, também, significações e tensões construídas no contexto das relações raciais e do racismo brasileiro. A discussão sobre a riqueza do trato do corpo negro e sobre os processos de opressão que o mesmo tem recebido ao longo da história pode vir a ser uma rica atividade pedagógica a ser desenvolvida com os alunos e as alunas em sala de aula, possibilitando debates e atividades sobre a história e a cultura afro-brasileira. Nesse processo, um estudo sobre o negro, o cabelo crespo e as práticas corporais pode ser um bom caminho. (GOMES, 2003, p. 174).
\end{abstract}

Mas, se por um lado, a afirmação da corporeidade e estética negra apresenta grande potencialidade como estratégia de combate à práticas racistas que, historicamente, desqualificaram esses elementos estéticos, por outro lado, como toda estratégia de afirmação de identidades, é necessário avaliar riscos e não perder de vista o caráter histórico dessas construções, sobretudo quando remetem a elementos que tendem a ser naturalizados, como é o caso da aparência física e dos padrões de beleza a ela associados.

As ponderações dos autores aqui apresentados e de tantos outros que se debruçam sobre o tema das identidades nos mostram que alguns dos dilemas e controvérsias expressos no texto das Diretrizes Curriculares... têm uma amplitude maior, apresentando-se como desafios para o movimento mundial de combate ao racismo pela via da afirmação da negritude. As polêmicas estão presentes também no interior do movimento negro, em que "podem-se ouvir vozes dissidentes, que não concordam com a definição forçosamente essencialista que toda formação étnica requer." (GUIMARÃES, 2005, p. 61).

Retomando o texto das Diretrizes Curriculares..., outro ponto de questionamento sobre o tratamento dado à questão das identidades refere-se ao fato de que o documento parece favorecer uma certa concepção de ensino de história como 
refém do processo de constituição de identidades, ou, mais especificamente, da promoção de uma identidade negra. Sem negar o papel do ensino de história no processo de constituição de identidades, e sua potencialidade para ampliar o leque de opções e favorecer a escolha de novas preferências identitárias pelos sujeitos aí envolvidos, Pereira (2008) nos adverte para o risco de transformar esse ensino em uma prática predominantemente "catequética", em que "as finalidades da educação histórica de pessoas negras seja uma formação identitária predeterminada, também neste caso concebida de forma essencialista". Reconhecer a dimensão das "estratégias de identidade" que o ensino de história favorece - ou pode favorecer - sem aprisioná-lo em uma finalidade exclusivista e restritiva é um dos desafios que se colocam hoje para o ensino dessa disciplina, para além da temática racial ou da abordagem da história e cultura africana e afro-brasileira.

Na mesma direção, Abreu e Mattos (2008) também reclamam um ensino de história capaz de desvendar a historicidade da construção de conceitos, evidenciando os conflitos e jogos de força que representam.

\footnotetext{
Assumir naturalmente a existência de identidades negras ou de uma cultura afro-brasileira é perder a dimensão das lutas travadas em torno da construção de identidades - mestiça, indígena, popular, brasileira ou regional - ao longo da história do Brasil. Sendo assim, é preciso chamar a atenção para a importância de pensar a história dos conceitos da cultura negra (e/ou afrobrasileira) e das identidades negras. (ABREU; MATTOS, 2008, p. 13).
}

\section{Culturas afro-brasileiras e seu tratamento no texto das Diretrizes Curriculares Nacionais para a Educação das Relações Étnico-raciais e para o Ensino de História e Cultura Africana e Afro-brasileira}

As questões identificadas em relação ao tratamento da identidade negra estão intimamente associadas às questões geradas pelo pressuposto de "uma" cultura negra ou afro-brasileira, também como realidade fixa, homogênea e dada a partir de uma origem comum ou de uma matriz cultural de referência. A compreensão da dinamicidade e descontinuidade presente em qualquer sistema cultural nos demanda uma análise crítica de propostas que se fixam na busca de elementos culturais "originais", "puros" ou "autênticos".

Cuche (2002, p. 140) nos lembra que "Não existem [...], de um lado as culturas 'puras' e de outro, as culturas 'mestiças'. Todas, devido ao fato universal dos contatos 
culturais, são, em diferentes graus, culturas 'mistas', feitas de continuidades e de descontinuidades."

Stuart Hall é um dos autores que se propõe a discutir o que chama de "culturas diaspóricas", combatendo tanto as ideias de pureza quanto de homogeneidade das culturas e identidades negras. No texto Que 'negro' é esse na cultura negra?, ele nos provoca:

Significa insistir que na cultura popular negra, estritamente falando, em termos etnográficos, não existem formas puras. Todas essas formas são sempre o produto de sincronizações parciais, de engajamentos que atravessam fronteiras culturais, de confluências de mais de uma tradição cultural, de negociações entre posições dominantes e subalternas, de estratégias subterrâneas de recodificação e transcodificação, de significação crítica e do ato de significar a partir de materiais preexistentes. Essas formas são sempre impuras, até certo ponto hibridizadas a partir de uma base vernácula. (HALL, 2003, p. 343).

E ainda: "Mas é para a diversidade e não para a homogeneidade da experiência negra que devemos dirigir integralmente a nossa atenção criativa agora." (HALL, 2003, p. 346). Lívio Sansone (2007) é outro autor que problematiza a ideia de cultura negra, propondo que se reconheça as várias perspectivas e a multiplicidade de elementos que participam das definições e construções em torno desse conceito, lembrando que ele é sempre contextualizado e, como tal, não pode ser facilmente transformado em ferramenta de análise.

\begin{abstract}
Por definição, nem todas as pessoas que podem ser definidas como negras num contexto específico participam da cultura negra o tempo todo. Por essa razão, qualquer definição que dermos da cultura negra e que tente apontar para uma essência supostamente universal das coisas negras será um cobertor curto, que não conseguirá cobrir todos os grupos dentro da população negra. De fato, se, para fins de pesquisa, muitas vezes é necessário definir o que significa a cultura negra num determinado contexto, é preciso sabermos que essa definição é sempre arbitrária e que a expressão "cultura negra", similarmente a outras que se associam à etnicidade e à "raça", tem que ser entendida como uma categoria nativa que não pode ser transformada com facilidade numa ferramenta de análise (SANSONE, 2007, p. 23).
\end{abstract}

Ao analisarmos a abordagem das culturas afro-brasileiras ou negras no texto das Diretrizes Curriculares... também encontramos contradições e paradoxos, como os já identificados em relação ao conceito de identidade.

Em alguns trechos do documento emerge uma concepção de "cultura afrobrasileira ou negra", no singular, e em contraposição a uma cultura europeia, também no 
singular "Convivem, no Brasil, de maneira tensa, a cultura e o padrão estético negro e africano e um padrão estético e cultural branco europeu." (BRASIL, 2004, p. 14).

Além de unificar a cultura e padrão estético - tanto africano quanto europeu desconsiderando a diversidade, os processos de troca cultural e hibridização presentes em cada uma dessas matrizes, o texto traz uma associação direta entre "negro" e "africano", como se fossem sinônimos, denotando uma certa nostalgia e recurso às "origens africanas", a uma cultura capaz de "redimir e repurificar", enquanto mote de mobilização e "estratégia de identidade". Seriam todas as culturas ditas "negras" ou "afro-brasileiras" originárias de práticas culturais africanas? Como lidar com as descontinuidades ou mesmo com a originalidade e potencial criativo e transformador dos africanos escravizados e seus descendentes, ao reinventarem novas práticas culturais? A esse respeito, Mattos e Abreu (2006) nos dizem que:

\begin{abstract}
Se em termos políticos é bastante compreensível a utilização dos conceitos de cultura negra e/ou afro-brasileira, deve-se levar em conta com profundidade seus limites em termos interpretativos ou descritivos. O que realmente é negro na cultura brasileira ou, como formulou Stuart Hall, "que 'negro' é esse na cultura negra"? Os negros não poderiam partilhar da dita cultura europeia ou branca? E os reconhecidos brancos não poderiam se identificar com práticas culturais costumeiramente atribuídas aos descendentes de africanos no Brasil? [...] também é importante pensar as descontinuidades, ou o que os descendentes de africanos fazem (ou fizeram) no Brasil que não se encontra na África. Como pensar a herança africana nas Américas? Até que ponto os africanos não criaram uma nova cultura, nesse sentido mais (ou tanto mais) americana e brasileira que africana? (MATTOS; ABREU, 2006, p. 55).
\end{abstract}

As autoras nos lembram que tais questões não são problemáticas apenas no texto das Diretrizes Curriculares..., mas se apresentam como desafios conceituais para os profissionais da história, não somente os educadores, posto que a história da cultura afro-brasileira e africana não tem recebido a devida atenção e reflexão teórica que requerem.

Ressaltando o "caráter desavergonhadamente híbrido" das culturas da diáspora, Mattos (2003) propõe fugir à tentação dos essencialismos culturais e descortinar o fato de que: "A construção de uma identidade negra positiva nas Américas não se fez como contrapartida direta da existência ou da 'sobrevivência' de práticas culturais africanas no continente, mas como resposta ao racismo e à sua difusão nas sociedades americanas.” (MATTOS, 2003, p. 129).

Todas essas reflexões contribuem para evidenciar as especificidades da presença africana no Brasil escravista e o surgimento, a partir daí, de culturas originais e 
dinâmicas, influenciadas e influenciando, de forma significativa, as culturas com as quais se defrontaram, tanto as de matriz indígena quanto as europeias.

Não podemos esquecer, entretanto, de que esta reciprocidade de influência raramente será simétrica, o que nos remete ao fato de que as culturas produzidas a partir da presença africana e afro-descendente, no Brasil, embora participando de trocas e intercâmbios diversos, ocuparam - e ainda ocupam -, um lugar de marginalidade e de desvalorização social, ou, quando muito, um tipo de valorização marcado pelo viés da folclorização, daquilo que é considerado exótico ou exuberante. Dessa forma, algumas manifestações culturais consideradas como parte das matrizes afro-brasileiras passaram a ter um tipo de aceitação social e serem até reconhecidas como expressões da "cultura nacional", sobretudo a partir do governo Vargas (1930-1945; 1950-1954). Outras continuaram a ser fortemente estigmatizadas e rejeitadas socialmente, como por exemplo, aquelas ligadas à religiosidade de matriz africana e/ou afro-brasileira, especialmente o candomblé e a umbanda.

Tudo isso nos ajuda a compreender porque uma das reivindicações históricas dos movimentos negros recaia sobre a necessidade de reconhecimento e valorização das expressões culturais que têm como referência - sem desconhecer todo o processo de hibridização e descontinuidades que lhes são intrínsecos - elementos culturais trazidos pelos africanos e reatualizados por seus descendentes.

As orientações presentes nas Diretrizes Curriculares... se afinizam com essa compreensão, na medida em que atribuem centralidade à abordagem das culturas africanas e afro-brasileiras, numa perspectiva positivada. Vale a pena, entretanto, problematizarmos algumas das concepções expressas por este documento.

Sabemos que, ao longo de nossa história, tem prevalecido a abordagem das culturas afro-brasileiras pelo viés do folclore, com ênfase para o que é considerado tradicional - e, portanto, menos permeável às mudanças -, como sendo mais representativo dessa produção cultural. No texto das Diretrizes Curriculares... também é possível identificar tal ênfase, quando, por exemplo, faz referência a um "jeito próprio de ser, viver e pensar manifestado tanto no dia-a-dia, quanto em celebrações como congadas, moçambiques, ensaios, maracatus, rodas de samba, entre outras" (BRASIL, 2004, p. 22). Parece-nos que o risco consiste não apenas em se considerar tais manifestações como principais ícones de uma cultura a ser valorizada e legitimada, mas também o de perder de vista que tais manifestações têm história, são "manifestações 
culturais vivas, ligadas a lutas políticas e sociais atuais e, portanto, sujeitas a transformações de significados ao longo do tempo." (ABREU; MATTOS, 2008, p. 16).

A eleição de alguns elementos como mais representativos da produção cultural de africanos e afro-descendentes, além de dificultar a percepção da diversidade de práticas e manifestações culturais construídas por estes sujeitos, ao longo da história, também costuma vir acompanhada de uma perspectiva mitificadora e idealizadora, bastante comum, por exemplo, na abordagem da história e cultura do continente africano.

Compreendendo as motivações políticas que geram uma "elaboração mitificada da mãe-África", enquanto elemento capaz de constituir laços de identidade e resistência, deve-se, no entanto, atentar para os riscos aí contidos. Pereira (2008) nos alerta para a necessidade de evitar

[...] um cenário por vezes idílico, épico, glorioso, mítico ou até mesmo "primitivo" da África, além de uma imagem da "cultura" da África também homogeneizada. [e ainda] a difusão de uma idealização da história do continente, principalmente em seu período pré-colonial, em que a colonização não raro figura como único processo responsável pelo quadro de devastação contemporânea do continente e pela destruição de suas matrizes culturais genuínas. (PEREIRA, 2008, p. 35).

Homogeneização e mitificação cultural, idealização e vitimização histórica são, assim, lados de uma mesma moeda, usada para vender uma imagem de África que muitas vezes não considera as contradições, heterogeneidades e conflitos que fazem parte de processos históricos diversos, vivenciados tanto no interior do próprio continente quanto nas relações estabelecidas com outros povos (LOPES, 1995). Além disso, corre-se o risco de supor uma história da África desvinculada da história de outros continentes, ou de apenas se inverter os polos de uma tão criticada abordagem eurocêntrica da história, mantendo-se intocada a lógica que a preside. Se é fato que a história africana esteve - e em grande medida, ainda está - ausente dos currículos tanto da Educação Básica quanto do Ensino Superior, sua inclusão exige abordagens que privilegiem a dimensão processual e relacional da história, como ademais de qualquer outro conteúdo. E, se compreendemos que uma visão positivada da história africana e afro-brasileira atende ao momento político de enfrentamento do racismo, devemos, no entanto, estar atentos para a tênue fronteira entre positivação e idealização/mitificação, entre, por um lado, trazer o foco para sujeitos, grupos e espaços tradicionalmente 
desconsiderados e/ou desqualificados, ou, por outro lado, des-historicizar a atuação desses sujeitos e grupos.

A abordagem das culturas afro-brasileiras exige especial atenção, pelos riscos aqui descritos, e levando em consideração que estas têm se apresentado como importantes referências - e talvez mesmo como principais expoentes - do trabalho desenvolvido nas escolas, neste contexto de implementação da Lei $n^{\mathbf{o}}$ 10.639/03, conforme apontou a pesquisa que desenvolvemos em um município mineiro ${ }^{12}$. Compreender o que está sendo reconhecido como "culturas afro-brasileiras", ou o que está sendo privilegiado como exemplo de manifestações culturais nos currículos escolares, neste momento, é um dos desafios a serem enfrentados pelas pesquisas acadêmicas, nos próximos anos.

\section{Datas, heróis, acontecimentos: novos conteúdos, velhas abordagens?}

Por fim, vale problematizar algumas das orientações presentes nas Diretrizes Curriculares... referente ao estudo de personagens negros e ao privilégio de datas significativas ou ressignificadas.

Sabemos que, há algumas décadas, o ensino de história vem sendo alvo de severas críticas, destacando-se a necessidade de ultrapassar uma abordagem pautada pela memorização acrítica de datas, acontecimentos, nomes de personagens e seus "grandes feitos", a serem celebrados a partir de um calendário cívico ou comemorativo.

Tais questões devem ser levadas em consideração ao examinarmos algumas das "Determinações" apresentadas pelas Diretrizes Curriculares..., referentes tanto ao estudo de datas consideradas "significativas", quanto à apresentação de uma listagem de nomes de personagens negros, africanos e afro-descendentes, que devem ser estudados, como exemplos da atuação de negros em diferentes áreas. Seriam tais indicações uma reedição do chamado "ensino tradicional", trocando-se apenas as datas e os personagens, sem alterar sua lógica e concepção? Que papel cumprem - ou ainda podem cumprir - as datas cívicas e/ou comemorativas e o estudo de personagens históricos? Em que medida, tais orientações podem contribuir para a cristalização de antigas abordagens e estratégias há muito presentes no ensino de história, e nas práticas escolares, em geral?

\footnotetext{
${ }^{12}$ Referimo-nos ao município de Contagem, localizado na região metropolitana de Belo Horizonte, lócus da investigação que resultou na tese "Saberes e práticas em Redes de Trocas: a temática africana e afrobrasileira em questão" (FAE/UFMG, 2010).
} 
Vale lembrar que as datas, organizadas em calendários cívicos, ainda parecem ter muita força dentro da organização das atividades escolares. Portanto, não são as Diretrizes Curriculares... as responsáveis por provocar ou instituir esse tipo de abordagem. No entanto, ao incluir tal perspectiva entre suas prescrições, o texto não estaria contribuindo para uma continuidade de práticas curriculares pautadas pela alocação de determinados temas em datas especiais do calendário, e muitas vezes, somente nessas datas? Reconhecemos que as datas comemorativas podem ser boas oportunidades para se pensar os significados socialmente construídos em torno de alguns eventos históricos, podendo se transformar em momentos valiosos para a percepção de processos de reatualização - ou reconfiguração - de memórias históricas. Entretanto, um ensino de história que reforce uma perspectiva celebrativa, sem questionamentos e reflexões sobre a própria data como construção social e histórica - e, portanto, fruto de disputas e jogos de força entre grupos sociais distintos -, parece se colocar na contramão de um movimento em prol de um ensino de história capaz de desconstruir realidades fixas e, assim, ajudar a desnaturalizar o mundo social.

O 13 de maio, por exemplo, é uma das datas tradicionais dos calendários escolares e também comemorada em algumas comunidades negras, em abordagens que têm contribuído, ao longo da história, para perpetuar uma ideia de abolição como dádiva da princesa Isabel, sem qualquer protagonismo negro (SCHWARCZ, 2009). Não por acaso, os movimentos negros rejeitaram essa data e propuseram sua re-significação, transformando-a em "Dia Nacional de Denúncia contra o Racismo".

Entretanto, se não for possível compreender que essa data tem história, que ela tem, teve e terá significados diversos, em diferentes contextos, contribuindo de maneiras variadas para a superação ou manutenção do racismo em nossa sociedade, corremos o risco de alterar as legendas, sem, entretanto, mudar substancialmente a paisagem. Quer dizer, o 13 de maio pode ser o dia de uma abolição dadivosa, ou um dia de denúncia do racismo, sem ser, em ambos os casos, um momento de reflexões sobre como os processos históricos são constantemente reconstruídos e re-significados, talvez este sim, um caminho interessante para a superação de dogmas e verdades que parecem inquestionáveis.

Da mesma forma, as disputas em torno da instituição do dia 20 de novembro como "Dia nacional da Consciência Negra" também merecem ser compreendidas numa perspectiva histórica, como fruto das lutas sociais que emergiram nas últimas décadas 
do Século $\mathrm{XX}^{13}$ e que se desdobram em polêmicas e embates no cenário social, como por exemplo, a luta pela sua transformação em feriado nacional.

Concordamos, assim, com Mattos e Abreu (2006), quando nos dizem:

\begin{abstract}
É possível, porém, problematizar, historicamente, os contextos em que foram instituídas, não apenas no Brasil, datas cívicas ligadas à afirmação da consciência negra ( 20 de novembro) e à luta contra o racismo (13 de maio e 21 de março). Historicizar tais datas comemorativas, confrontando com documentos de época, apresenta-se como excelente forma de ensinar, de uma perspectiva crítica e dinâmica, a história das relações étnico-raciais no Brasil, suas relações com a memória da experiência da escravidão e da abolição, e suas mudanças na nossa história recente. (MATTOS; ABREU, 2006, p. 56).
\end{abstract}

Esta perspectiva, entretanto, não aparece claramente no texto das Diretrizes Curriculares..., que acabaram se reduzindo a uma prescrição de como deverão ser tratados o 13 de maio, o 20 de novembro e o 21 de março.

Em relação ao estudo de personagens negros, também não se encontra no texto das Diretrizes Curriculares..., ponderações e alertas sobre os riscos de transformar tais personagens em novos heróis, mantendo intocada a lógica que atribui a determinados sujeitos a responsabilidade exclusiva pela condução de processos históricos. É fato que as biografias vêm sendo, mais recentemente, revalorizadas no âmbito da produção do conhecimento histórico e que esse tipo de trabalho pode contribuir, inclusive, para uma percepção de que a história é feita por "pessoas de carne e osso", gente que faz, sente, vive experiências concretas, em seu dia-a-dia. Neste sentido, reconhecemos que o foco em alguns personagens históricos pode ser uma boa estratégia para perceber o protagonismo negro em diversos campos de atuação, conforme apontam as Diretrizes Curriculares...

Mas, novamente aqui, não se pode desconsiderar que o ensino de história tem história, o que inclui lutas históricas pela superação de determinadas abordagens, cujos resultados têm sido apontados como bastante danosos na formação das novas gerações. É preciso levar em conta a tradição de heroicização de personagens que acompanhou e, por sinal, ainda acompanha - o ensino dessa disciplina na escola básica, sobretudo nos primeiros anos de escolarização. Assim, se o estudo de personagens negros, quase sempre negado na trajetória histórica do ensino de história, pode ser uma boa estratégia para o reconhecimento do protagonismo negro na história brasileira - ou africana, ou

\footnotetext{
${ }^{13}$ Mattos et al (2009, p. 303) nos dizem que, "[...] de acordo com Silvia Lara (1995, p. 9), foi a partir do Movimento Negro Unificado (MNU), em 1978, que se instituiu o dia da morte de Zumbi - 20 de novembro - como o Dia Nacional da Consciência Negra".
} 
mundial - também pode se transformar em uma velha edição do processo de heroicização, que em nada contribui para a percepção da história como processo social, coletivo, partilhado por grupos diversos, a partir de relações quase sempre conflituosas e contraditórias. Mattos e Abreu (2006) também evidenciaram tal preocupação, ao mesmo tempo em que reconhecem as potencialidades dos estudos biográficos, quando nos dizem:

\begin{abstract}
Por outro lado, uma abordagem crítica das biografias sugeridas permitiria historicizar, através de exemplos concretos, as formas diferenciadas de ser negro e de se conviver com a presença do racismo nos diversos contextos da história brasileira. $\mathrm{O}$ que significava ser um negro rico e culto em plena vigência da escravidão, como foram, por exemplo, os irmãos Antônio e André Rebouças? O quanto a condição de liberto marcou a ação política de homens como Toussaint Louverture ou Luís Gama? Qual o papel dos intelectuais negros nas lutas anti-racistas do século XX? Associadas a questões específicas, tais histórias de vida podem deixar de ser uma tentativa de construção de contra-heróis para se tornar uma ferramenta eficaz, porque ligada a experiências concretas, de abordagem da questão de como, apesar de difuso, o preconceito racial na sociedade brasileira se manifesta e racializa, gostem eles ou não, uma parte expressiva de sua população. (MATTOS; ABREU, 2006, p. 57).
\end{abstract}

Mais uma vez, podemos dizer que as orientações apresentadas nas Diretrizes Curriculares... omitem tais possibilidades, deixando sob responsabilidade dos docentes a construção de alternativas para se evitar o risco de heroicização acrítica, pressupondo, inclusive, que sejam capazes de uma avaliação prévia desses riscos. Tal aposta pode ser frustrada, se pensarmos na realidade da formação de professores no Brasil e, especialmente, se levarmos em conta que boa parte dos professores envolvidos no trabalho com a temática africana e afro-brasileira possuem formações distintas e, quase sempre, tiveram pouca oportunidade de contato com esse tipo de discussão, mais presente no campo do ensino de história.

Pode-se ponderar que não caberia ao texto legal tal nível de especificação e prescrição, frente à necessidade de garantir a autonomia docente em relação às escolhas pedagógicas. No entanto, quando identificamos uma lista de personagens sugeridos como possibilidades de estudo, percebemos que o nível de detalhamento, neste caso, não foi considerado um problema. A tensão entre ser mais prescritivo ou mais aberto se faz presente no texto das Diretrizes Curriculares..., sendo mais uma evidência de seu caráter polissêmico e portador de diferentes vozes.

No entanto, como bem nos aponta Pereira (2008), ao analisar alguns dos dilemas e desafios colocados no campo da recepção à Lei n ${ }^{\circ}$ 10.639/03: 
Se, por um lado, essa diversidade de interpretações é um valor, sobretudo pela possibilidade de capturar prescrições várias, também passíveis de adaptação às diferentes realidades escolares, por outro, essa mesma qualidade pode se transformar num problema, em especial para professores que não dispõem de interlocução substantiva e permanente capaz de fundamentar e reorientar suas escolhas. (PEREIRA, 2008, p. 22).

As análises aqui propostas acerca do texto das Diretrizes Curriculares... não tiveram a pretensão de esquadrinhar todo o seu conteúdo, ou de esgotar os tantos sentidos e possíveis interpretações a que o texto se abre. Além disso, o fato de procurarmos desenvolver uma análise crítica nos conduziu a uma identificação de alguns dos problemas e contradições aí presentes, tanto no campo das concepções e aportes teóricos, quanto em relação às orientações pedagógicas.

Vale reafirmar, entretanto, que a análise crítica aqui proposta não invalida o reconhecimento do valor político e estratégico que a Lei $\mathrm{n}^{\circ} 10.639 / 03$ e suas Diretrizes correlatas têm representado no contexto de combate ao racismo e de educação das relações étnico-raciais, elementos fundamentais para a construção de uma sociedade mais justa e igualitária, em nosso país.

\title{
Teaching History and The 10.639/03 Law: dialogues between fields of knowledge, curriculum guidelines and practical challenges
}

\begin{abstract}
In recent years we have witnessed the emergence of an educational legislation whose emphasis is on dealing with the socio-cultural diversity in school curricula. The 10.639/03 Law, mandating the teaching of African history and culture and african-Brazilian basic education, and Law No. $11.645 / 08$, which side of this issue also includes the Indian question as obligatory curriculum, this fall process. The approach of cultures traditionally denied or silenced in the curriculum is understood as an important strategy for combating inequalities historically perpetuated in our society, aiming at the development of a re-education of ethnic-racial relations. This text seeks to elucidate aspects of the interface between academic production - especially the production of the historiographical field on the African continent and the black slavery - the Law 10.639/03 and its related curriculum guidelines and teaching of history, seeking to highlight some of the challenges now arise to practice teaching of basic education teachers who take responsibility to work such content.
\end{abstract}

Key words: African history and culture and african-Brazilian, anti-racist Education, Historiography, History teaching. 


\section{Referências}

ABREU, Martha. Outras histórias de Pai João: conflitos raciais, protesto escravo e irreverência sexual na poesia popular, 1880-1950. Afro-Ásia, Centro de Estudos AfroOrientais-CEAO, FFCH/UFBA, Salvador, n. 31, p. 235-276, 2004.

ABREU, Martha; MATTOS, Hebe Maria. Em torno das Diretrizes curriculares nacionais para a educação das relações étnico-raciais e para o ensino de história e cultura afro-brasileira e africana: uma conversa com historiadores. Estudos Históricos, Rio de janeiro, v. 21, n. 41, p. 5-20, jan./jun. 2008.

APPIAH, Kwame Anthony. Identidades africanas. In: APPIAH, Kwame Anthony. Na casa de meu pai: a África na filosofia da cultura. Rio de Janeiro: Contraponto, 1997. p. 241- 251.

ARNAUT, Luiz; LOPES, Ana Mônica. História da África: uma introdução. Belo Horizonte: Crisálida, 2005.

BRASIL. Ministério da Educação/SECAD/Secretaria Especial de Políticas de Promoção da Igualdade Racial-SEPPIR. Diretrizes Curriculares Nacionais para a Educação das Relações Étnico-Raciais e para o Ensino de História e Cultura Afro-Brasileira e Africana. Brasília, 2004.

BRASIL. Presidência da República. Lei no 10.639, de 9 de janeiro de 2003. Altera a Lei $\mathrm{n}^{\circ}$ 9.394, de 20 de dezembro de 1996, que estabelece as diretrizes e bases da educação nacional, para incluir no currículo oficial da rede de ensino a obrigatoriedade da temática "História e Cultura Afro-Brasileira", e dá outras providências. Brasília, 2003.

CAIMI, Flávia Eloísa. Conversas e controvérsias: o ensino de história no Brasil (1980-1998). Passo Fundo: UPF, 2001.

CASTRO, Hebe. História Social. In: CARDOSO, Ciro Flamarion; VAINFAS, Ronaldo (Org.). Domínios da História: ensaios de teoria e metodologia. Rio de Janeiro: Campus, 1997. p. 45-59.

CHALHOUB, Sidney. Visões da Liberdade: uma história das últimas décadas da escravidão na corte. São Paulo: Companhia das Letras, 1990.

CUCHE, Denys. A noção de cultura nas ciências sociais. 2. ed. Bauru, SP: EDUSC, 2002. $255 \mathrm{p}$.

FLORENTINO, Manolo. Introdução. Revista Brasileira de História, São Paulo, v. 26, n. 52, dez. 2006. Disponível em: <http://www.scielo.br/scielo.php?script=sci_arttext \&pid=S0102-01882006000200002 \&lng=pt\&nrm=iso\&tlng=pt>. Acesso em: 02 fev. 2010.

FREYRE, Gilberto. Casa-grande \& senzala. 39 ed. Rio de Janeiro: Record, 2000. 
GOMES, Nilma Lino. Educação, identidade negra e formação de professores/as: um olhar sobre o corpo negro e o cabelo crespo. In: Educação e Pesquisa, São Paulo, v. 29, n.1, p. 167-182, jan./jun. 2003. Disponível em: <http://www.scielo.br/scielo.php? script=sci_arttext\&pid=S1517-97022003000100012\&lng=pt\&nrm=iso\&tlng=pt $>$.

Acesso em: 04 mar. 2010.

GUIMARÃES, Antonio Sérgio Alfredo. Racismo e Anti-Racismo no Brasil. São Paulo: Fundação de Apoio à Universidade de São Paulo; Ed. 34, 2ª ed., 2005.

HALL, Stuart. Que "negro" é esse na cultura negra? In: HALL, Stuart (Org.). Da Diáspora: identidades e mediações culturais. Liv Sovik; Tradução Adelaine La Guardia Resende et al Belo Horizonte: Editora UFMG; Brasília: representação da UNESCO no Brasil, 2003, p. 335-349.

LAVILLE, Christian. A guerra das narrativas. In: Revista Brasileira de História, São Paulo, v. 19, n. 38, p. 125-138.

LOPES, Alice Ribeiro Casimiro. Conhecimento escolar: ciência e cotidiano. Rio de Janeiro: Ed. UERJ, 1999.

LOPES, Carlos. A pirâmide invertida - historiografia africana feita por africanos. In: Actas do Colóquio “Construção e Ensino da História da África”. Lisboa, Portugal: Linopazas, 1995. p. 21-29.

MATTOS, Hebe Maria. O ensino de História e a luta contra a discriminação racial no Brasil. In: ABREU, Martha; SOIHET, Rachel (Org.). Ensino de História: conceitos, temáticas e metodologia. Rio de Janeiro: Casa da Palavra, 2003, p. 127-136.

MATTOS, Hebe Maria; ABREU, Martha. Subsídios para uma leitura crítica dos PCNs e das Diretrizes Curriculares Nacionais para a educação das relações étnico-raciais e para o ensino de história e cultura afro-brasileira e africanas. In: BARROS, José Márcio et al. Ensino de história e cultura africana e afro-brasileira. Belo Horizonte: PUC Minas Virtual, 2006, p. 49-59.

MATTOS, Hebe Maria; ABREU, Martha; DANTAS, Carolina Vianna; MORAES, Renata. Personagens negros e livros didáticos: reflexões sobre a ação política dos afrodescendentes e as representações da cultura brasileira. In: ROCHA, Helenice Aparecida Bastos et al. (Org.). A história na escola: autores, livros e leituras. Rio de Janeiro: Editora FGV, 2009, p. 299-320.

MOORE, Carlos. A África que incomoda: sobre a problematização do legado africano no quotidiano brasileiro. Belo Horizonte: Nandyala, 2008.

OLIVA, Anderson Ribeiro. A História da África nos bancos escolares: representações e imprecisões na literatura didática. Revista Estudos Afro-Asiáticos, ano 25, n. 3, set./dez. 2003. Disponível em: <http://www.scielo.br/scielo.php?script=sciarttext $\&$ pid=S0101-546X200300030000 3 \&lng=pt\&nrm=iso\&tlng=pt $>$. Acesso em: 02 maio 2009. 
OLIVA, Anderson Ribeiro. O Ensino da História da África em debate (Uma Introdução aos Estudos Africanos). In: MEDEIROS, Cléia; EGHRARI, Iradj Roberto (Org.). História e Cultura Afro-Brasileira e Africana na Escola. Brasília: Ágere Cooperação em Advocacy, 2008. p. 29-49.

PEREIRA, Junia Sales. Reconhecendo ou construindo uma polaridade étnicoidentitária? Desafios do ensino de história no imediato contexto pós-Lei $\mathrm{n}^{\mathrm{o}} 10.639$. In: Estudos Históricos, Rio de janeiro, v. 21, n. 41, p.21-43, jan./jun. de 2008.

QUEIRÓZ, Suely Robles Reis de. Escravidão negra em debate. In: Historiografia Brasileira em Perspectiva. São Paulo: Contexto, 1998, p. 103-117.

REIS, João José; SILVA, Eduardo. Negociação e conflito: a resistência negra no Brasil escravista. São Paulo: Cia. das Letras, 1989.

SANSONE, Lívio. Negritude sem etnicidade: o local e o global nas relações raciais e na produção cultural negra do Brasil. Tradução: Vera Ribeiro. Salvador: Edufba; Pallas, 2007.

SANTOS, Lorene dos. Saberes e práticas em Redes de Trocas: a temática africana e afro-brasileira em questão. Belo Horizonte: Faculdade de Educação da UFMG (Tese de Doutorado), 2010.

SCHWARCZ, Lilia Moritz. Nem preto nem branco, muito pelo contrário: cor e raça na intimidade. In: SCHWARCZ, Lilia Moritz (Org.). História da vida privada no Brasil: contrastes da intimidade contemporânea. São Paulo: Companhia das Letras, 1998, p. 173-244.

SCHWARCZ, Lilia Moritz. Racismo à brasileira. In: BARROS, José Marcio et al. Ensino de história e cultura africana e afro-brasileira: livro-texto. Belo Horizonte: PUC Minas Virtual, 2006. p. 36-48.

SCHWARCZ, Lilia Moritz. Abolição como dádiva. In: FIGUEIREDO, Luciano (Org.). A Era da Escravidão. Rio de Janeiro: Sabin, 2009 (Coleção Revista de História no Bolso), p. 88-90.

SHUlMAN, Lee S. Conocimiento y Enseñanza. In: Estudios Públicos/Centro de Estúdios Públicos. Santiago, Chile: Centro de Estudios Públicos, n. 83, invierno 2001. Disponível em: <http://www.cepchile.cl/dms/lang_1/doc_1573.html>. Acesso em: 12 maio 2009.

SILVA, Alberto da Costa e. Um Rio Chamado Atlântico: a África no Brasil e o Brasil na África. Rio de Janeiro: Nova Fronteira: Ed. UFRJ, 2003.

SOUZA, Laura de Mello e. O escravismo brasileiro nas Redes do Poder: comentário de quatro trabalhos recentes sobre escravidão colonial. Estudos Históricos, Rio de Janeiro, v. 2, n. 3, p. 133-152, 1989.

VIANNA, Hermano. Mestiçagem Fora de Lugar. Folha de S. Paulo, Caderno Mais!, São Paulo, 27/06/2004, p. 4-6. 